\title{
Storage stability of sweet biscuit elaborated with recovered potato starch from effluent of fries industry
}

\author{
Mariana Patricio de MORAIS ${ }^{1}$, Márcio CALIARI ${ }^{1 \star}$, Elizabeth Harumi NABESHIMA ${ }^{2}$, \\ Jaqueline Eduarda Rodrigues BATISTA ${ }^{1}$, Maria Raquel Hidalgo CAMPOS ${ }^{3}$, Manoel Soares SOARES JÚNIOR ${ }^{1}$
}

\begin{abstract}
The effluent from the potato chips processing could be recovered and used in the biscuit formulations. This study aimed to evaluate the changes of sweet biscuits with partial replacement (45\%) of wheat flour by recovered potato starch, packed in biaxial oriented polypropylene (BOPP), and stored under two controlled temperatures $\left(25^{\circ} \mathrm{C}\right.$ and $\left.35^{\circ} \mathrm{C}\right)$. The changes of physical, chemical, microbiological and sensory characteristics of biscuits were evaluated for 6 months. Completely randomized design with $2 \times 6$ factorial arrangement was employed. In the first 36 days of biscuits storage was no increase in water activity and this remained constant up to 144 days of storage, up next. The score for sensory texture reduced over time, which shows that the tasters preferred less hard biscuits, since there was an increasing trend of instrumental hardness during storage, probably due to starch retrogradation, facilitated by higher moisture biscuits. Sweet biscuits of wheat flour and potato starch acidified and dehydrated have good physical and microbiological conditions, being able to be consumed for a period of 180 days. Potato starch recovered after acidified and dehydrated can be used as an ingredient in the products development for human consumption, avoiding losses and environmental pollution, and to generate economic gains.
\end{abstract}

Keywords: Solanum tuberosum L.; physicochemical characteristics; texture; microbiological hazard; sensory analysis.

Practical Application: Partial replacement of wheat flour of sweet biscuit by potato starch recovered from fries processing effluent.

\section{Introduction}

In the fries production, potato pulp is usually lost with the tuber wash water released from the parenchyma cells after the potato is cut and before it is fried (Bastos et al., 2016). The residual starch or potato pulp is commonly discarded, can be harnessed for human consumption, if properly dried to be used as feedstock (Carvalho et al., 2014). Starchy residue recovered from the effluent of fries-processing industry can to reduce losses of the industry and to add value to the product (Batista et al., 2016).

Some industries, in addition to producing chips, other product lines, such as snacks (Dias et al., 2014). The recovered potato starch could be used as an ingredient in other products, which could increase the sustainability of the same.

Biscuits, cookies and crackers are snacks obtained by mixing flour(s) and starch(es) with other ingredients, undergo the kneading and cooking process, fermented or not. May have coverage, filling, format and various texture. The biscuits can be classified according to the ingredient that characterizes or presentation. Sweet biscuits or biscuits are products that contain sugar, in addition to normal substances used (Brasil, 2005).

This convenience bakery product has a good acceptability and consumed by people of any age. Its long shelf-life allows them to be produced in large quantities and widely distributed. A product with such characteristics, combined with its enormous diversity, proves to be a good vehicle for the study of composite flour, either for economic reasons, either for nutritional reasons (Baljeet et al., 2010).

According to Melo et al. (2004), the biscuit quality is related to the taste, texture, appearance and other factors which depend on interactions among various ingredients and processing conditions. Biscuits generally have low moisture content and its is advantageous as to microbiological aspects, resulting in long shelf-life if stored inside appropriate conditions (packaging material, environmental conditions, especially) (Adebowale et al., 2012).

There are many studies about biscuit using composite flour by different sources in substitution to wheat flour, such adding buckwheat flour (Baljeet et al., 2010), sorghum flour (Adebowale et al., 2012); defatted sesame flour (Clerici et al., 2013), but there are no studies on wheat substitution for recovered potato starch.

In this context, considering the problem of economic losses and environmental impact, and to verify whether the use of this new ingredient is safe for the sweet biscuit storage period, this 
study intends to evaluate the changes of sweet biscuits with partial replacement (45\%) of wheat flour by recovered potato starch from effluent of fries industry, obtained water washing after peeling and cutting tubers, packed in biaxial oriented polypropylene (BOPP), and stored under two controlled temperatures $\left(25^{\circ} \mathrm{C}\right.$ and $35^{\circ} \mathrm{C}$ ), during six months.

\section{Material and methods}

\subsection{Obtaining the raw material}

Potato starch (PS) of cultivar Atlantic was recovered in the fries production of the company line Cicopal, located in Senador Canedo, Goiás, Brazil. The other ingredients were purchased at a local market. The effluent was collected after the step of peeling, cutting and washing tubers, directly on the discharge pipe with the aid of polypropylene bag, at sufficient amount for the preparation and analysis of the sweet biscuit.

The PS was taken to the Laboratory of Utilization of Residues and Byproducts Agribusiness (Labdarsa), School of Agronomy, Federal University of Goiás and acidified with lactic acid solution absolute Sinth ${ }^{\oplus} 0.1 \mathrm{M}$, until the $\mathrm{pH}$ reached 3.7, value given by the digital potentiometer (Hanna Instruments, HI9224, Sigapore, China). The homogenization was performed with the aid of an industrial blender. After step drying was performed in an oven with forced air circulation at $60^{\circ} \mathrm{C}$ (Tecnal TE-394/3, Piracicaba-SP, Brazil). Then, the PS was stored under refrigeration at $5^{\circ} \mathrm{C}$, in bags of low density polyethylene (LDPE).

\subsection{Biscuits formulation and processing}

The formulation of sweet biscuit used PS ( $45 \mathrm{~g}$ ), wheat flour (55 g), sodium chloride (2.1 g), water (71 g), baking powder $(3 \mathrm{~g})$, fresh whole egg $(10 \mathrm{~g})$, margarine with $70{\mathrm{~g} 100 \mathrm{~g}^{-1} \text { lipids }}^{\circ}$ $(67.5 \mathrm{~g})$ and coconut essence $(15 \mathrm{~g})$. The dry ingredients and margarine were mixed manually in a bowl of stainless steel, and then added the remaining ingredients. In a stainless steel bench with the aid of a roll of polyethylene fluff, the mass was opened until it was a smooth surface and with height of about $5 \mathrm{~mm}$, molded with the aid of a metal pattern (template) of $40 \mathrm{~mm}$ in diameter, and the pieces placed in stainless steel tray, greased with margarine and wheat flour. The sweet biscuits were baked in an industrial oven (Venâncio, FCDT5, Venâncio Aires, Brazil) preheated for $25 \mathrm{~min}$ at temperature of $180^{\circ} \mathrm{C}$, cooled at room temperature, wrapped in the BOPP package, with thickness of $80 \mu \mathrm{m}$ (same used by Cicopal), and stored at $25^{\circ} \mathrm{C}$ and $35^{\circ} \mathrm{C}$ in biochemical oxygen demand incubators (BOD).

\subsection{Design of storage test}

Completely randomized design was used with a factorial scheme $(2 \times 6)$, two storage temperatures $\left(25^{\circ} \mathrm{C}\right.$ and $\left.35^{\circ} \mathrm{C}\right)$ and six evaluation periods $(0,36,72,108,144$ and 180 days $)$, and three original repetitions per treatment. Moisture, instrumental colour parameters, water activity, hydrogen potential $(\mathrm{pH})$, hardness, and sensory acceptance of sweet biscuits were evaluated. Q10 factors were calculated. The reaction order and speed of changes in water activity, moisture content and hardness of sweet biscuits also were calculated.

\subsection{Physical and physicochemical characteristics}

Instrumental colour parameters (Luminosity, Chroma $\mathrm{a}^{\star}$ and Chroma $\left.\mathrm{b}^{\star}\right)$ of Cielab System were measured with a colorimeter (Color Quest, Hunter, Virginia, Canada); pH with digital potentiometer (Hanna Instruments, HI9224, Singapore, China) (Association of Official Analytical Chemists, 2012); moisture was obtained by the weight loss of the sample, when heated at $105{ }^{\circ} \mathrm{C}$ to constant weight (Association of Official Analytical Chemists, 2012); and breaking strength or hardness (Stable Micro System, TA.HD. plus, Godalming, UK), with rectangular steel blade (blade Warner Bratzler \& reversible) to cut the biscuits in half, horizontally arranged on the platform, the pre-test and post-test speed $10 \mathrm{~mm} \mathrm{~s}^{-1}$, sensitivity $0.05 \mathrm{~N}$ strength, test speed of $2 \mathrm{~mm} \mathrm{~s}^{-1}$, the test distance $8 \mathrm{~mm} \mathrm{~s}^{-1}$, and readings performed in nine biscuits per sample, on the second day after its preparation (Stable Micro Systems, 2013).

\subsection{Kinetics of physico-chemical changes during storage}

To determine the reaction order and its rate constant values of water activity, moisture and hardness, its Ln and their inverses $(1 / \mathrm{Ln})$ versus storage time were plotted, and performed linear regression these values. The slope in the linear regression obtained corresponded to the values $\mathrm{k}$ (reaction rate constant). The Q10 was calculated by dividing the rate constants of the reaction at $35^{\circ} \mathrm{C}$ and $25^{\circ} \mathrm{C}$.

\subsection{Microbiological hazard and sensory acceptance}

Microbiological analyzes of Coagulase Positive Staphylococci, Coliforms at $45^{\circ} \mathrm{C}$ and research Salmonella sp of $25 \mathrm{~g}$ sample were performed with techniques described by the Food and Drug Administration (2002).

The acceptance test was applied to 50 tasters using a randomized block design, each panelist was considered a block, and a nine-point hedonic scale ( $9=$ like extremely, $5=$ neither liked and disliked $1=$ dislike extremely) (Stone et al., 2012). The attributes evaluated were appearance, odor, texture and flavour. The cutoff for the biscuit be deemed accepted by the tasters was equal/greater than six, which corresponds to "liked slightly" hedonic scale as the level of acceptance of experimental biscuits. The tasters adults (19-47 years) of both sexes, $42 \%$ female and $58 \%$ male, were recruited as interest and availability to participate in the research. The biscuits were served on paper plates, with two samples for each sample stored at $25^{\circ} \mathrm{C}$ and the other at $35^{\circ} \mathrm{C}$. The project was approved by the Ethics Committee under number 476932 protocol.

\subsection{Analysis of results}

Variance factorial analysis was performed to assess the significance of the time and temperature effects on the physical, physicochemical and sensory properties, then we determined the regression models, the significance level and the coefficient of determination, besides being constructed graphs with the aid of Statistica 7.0 and Microsoft Excel programs. To determine the physicochemical characteristics models kinetics, the model who obtained the best fit, with higher coefficient of determination and 
lower mean relative error was selected. Also obtained the significance level of Pearson correlations between the physicochemical and sensory parameters evaluated during storage.

\section{Results and discussion}

\subsection{Physical changes during storage}

Conform to Factorial Anova, storage time effect was significant $(\mathrm{p} \leq 0.01)$ on the moisture, water activity, luminosity, hardness and $\mathrm{pH}$ of sweet biscuits, also was significant $(\mathrm{p} \leq 0.05)$ on the Chrome $b^{*}$, and not significant for Chrome $a^{*}(p>0.05)$. Interactions were significant for $\mathrm{pH}(\mathrm{p} \leq 0.05)$, thus regression models were developed in storage time considering the different temperatures only for this characteristic. The other models are represented only by time. For moisture, the cubic model was further adjusted, and there was sigmoid behavior (Figure 1A).

A

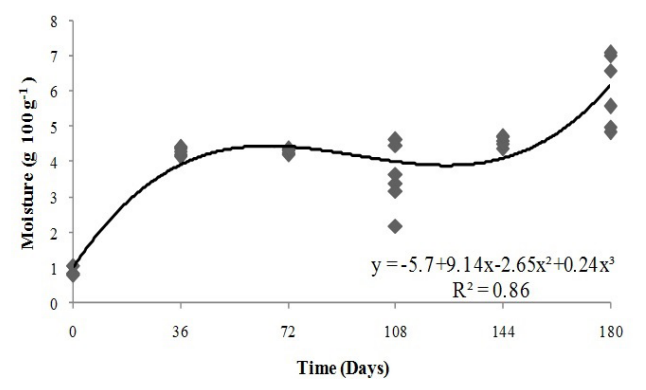

$\mathrm{C}$

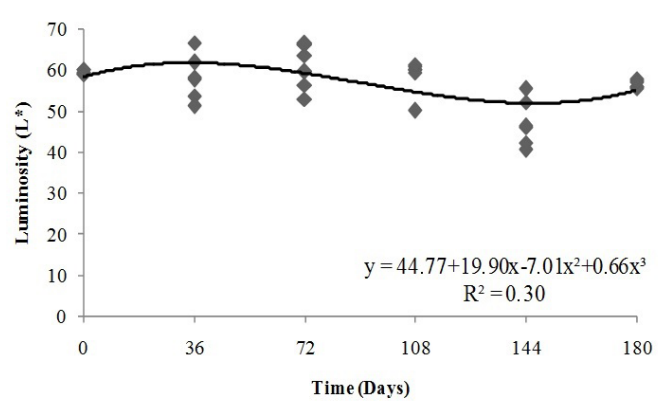

$\mathrm{E}$

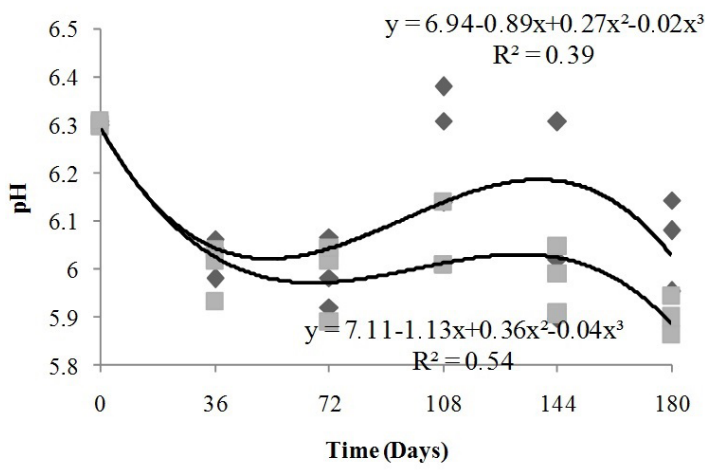

Until 36 days of storage was increased moisture. This initial increase was due to the balance between the vapor pressures within the packaging and within the BOD with moisture of sweet biscuits, depending on the rate of water vapor permeability of the packaging material. The packaging for biscuits should provide a barrier to moisture, water vapor, and light to any kind of contamination, as partially seen in packaging (PPBO) used in this research. When a food is subjected to an constant temperature atmosphere and high relative humidity $(\mathrm{RH})$ it absorbs water, and there is an increase in the moisture concentration (Syamaladevi et al., 2016).

From the 144 days of storage was observed increased moisture of sweet biscuits. This fact can be explained by the possible oscillation of the RH it absorbs water, and there is an increase in the moisture concentration. From the 144 days of storage was observed increased moisture of sweet biscuit. This fact can be explained by the possible oscillation of the $\mathrm{RH}$ since the BOD
B

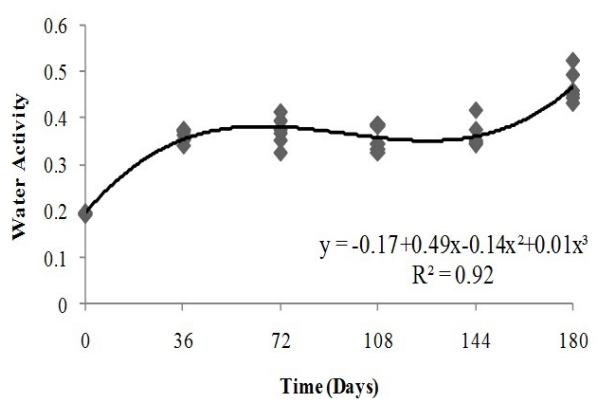

D

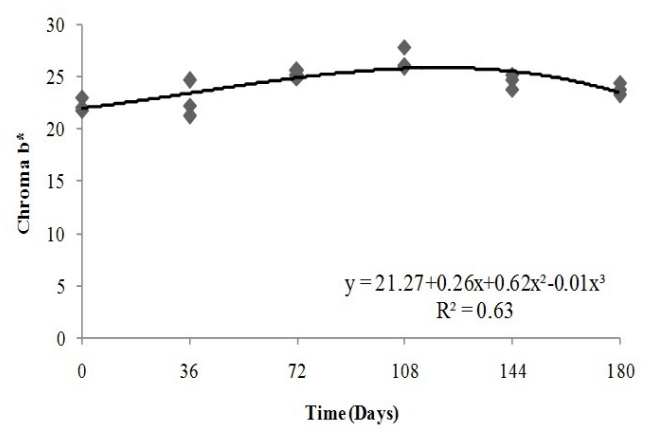

$\mathrm{F}$

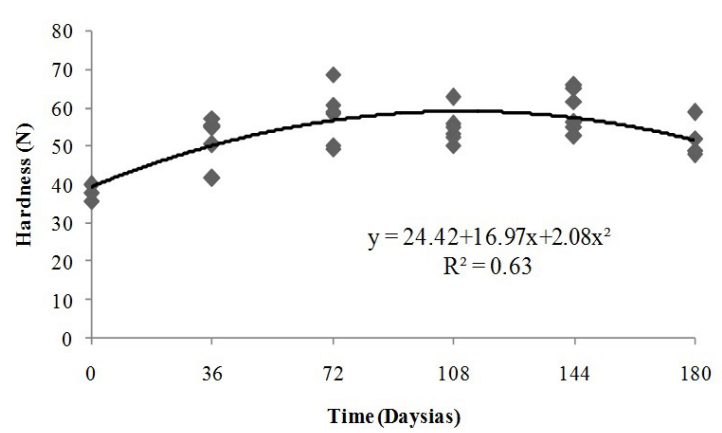

Figure 1. A: moisture $\left(100 \mathrm{~g}^{-1}\right)$; B: water activity; C: brightness; D: chroma $\mathrm{b}^{\star}$; E: pH; F: hardness $(\mathrm{N})$ of the sweet biscuits, stored for 180 days. 
controlled only for testing the internal temperature, not having influence on moisture. The sweet biscuit stored won moisture to come into equilibrium with the environment, because the rainfall index during this period was high in Goiânia. In the month of April typically occurs decrease in rainfall in the Midwest. But this phenomenon was not observed in 2014, where the accumulated rainfall in the city reached $304 \mathrm{~mm}$, and the historical average for the period is $120 \mathrm{~mm}$, which corresponds to a value of $152 \%$ above normal (Vendramini, 2014).

In the first 36 days of storage was increased water activity biscuits and this remained constant up to 144 days, it was found so a balance has been established in this period. Then there was increased water activity biscuits, reaching up to 0.5 , which can be attributed to the increased moisture of biscuits (Figure 1B).

Minimum water activity (aw) values to support the growth of representative spoilage microorganisms to Alicyclobacilli is 0.97, Pseudomonads 0.97, Enteric bacteria 0.95, Lactic acid bacteria 0.92 , Saccharomyces cerevisiae 0.92 , Spoilage yeasts 0.90 , Bacillus subtilis 0.90, spoilage molds 0.84, xerotrophic molds 0.62 , and osmophilic yeasts 0.60 (Sperber, 2009). Therefore, it is considered limiting value of 0.6 for microbial proliferation. The sweets biscuits were below the range for developing organism, if maintaining a microbiologically stable product after 180 days of storage, as evidenced by microbiological analysis.

The moisture was positively correlated (0.96) with water activity the $1 \%$ level of significance. The moisture and water activity as a function of storage time showed the same behavior, the sigmoid type. The sorption and desorption isotherms sigmoid shape curves are characteristic of many foods, such as farinaceous and proteinaceous materials such as flour, starches and modified starches (Ascheri et al., 2005).

Initially, water activity increased until reaching a plateau and an equilibrium. The time required to reach equilibrium intermediate varies according to the value of water activity and temperature in the adsorption process. Adsorption isotherms of most products formulated with starches present in its final portion, corresponding to higher water activity, more hygroscopic behavior, characterized by the rise of the curve. This behavior was also reported by Santos et al. (2004), who studied the adsorption of water seasoned cassava flour.

Luminosity values ranged $29.17 \%$ between 72 and 144 days (Figure 1C). Therefore, with the passage of time there was a slight tendency to the browning of the experimental sweet biscuits. In relation to the chrome $\mathrm{a}^{*}$ values, it is realized that the variation was very small $(6.2 \%)$ and not significant during the 180 days of storage at $35^{\circ} \mathrm{C}$. Probably due to the short storage time (180 days), and the quality of packaging (opaque BOPP), which did not allow the entry of light (photo typesetting pigment) nor oxygen (oxidation of pigments and browning of ascorbic acid). Thus no more pronounced variations in the color of the sweet biscuits were observed. The chrome $b^{*}$ sweet biscuits suffered gradual increase up to 144 days of storage at $35^{\circ} \mathrm{C}(10.13 \%)$, declining to 180 days, but still higher than the initial average (Figure 1D). Thus, there was a slight yellowing of the samples during storage.
In both storage temperatures, the $\mathrm{pH}$ biscuits showed the same sigmoid trend, but reverse the trend presented by moisture and water activity curves (Figure 1D). Therefore, the higher the $\mathrm{pH}$ was lower water activity. The reduction in $\mathrm{pH}$ of the sweet biscuits stored at $35{ }^{\circ} \mathrm{C}$ was higher than at $25^{\circ} \mathrm{C}$ storage temperature because the accelerated chemical reactions of the components biscuit (Law Van Toff). Biscuits $\mathrm{pH}$ values have changed during storage, causing a reduction close to $3.8 \%$ at $25^{\circ} \mathrm{C}$ and $6.4 \%$ at $35^{\circ} \mathrm{C}$ after 180 days of storage. This phenomenon may be due to the chemical composition of the sweet biscuit because salts and sugar were added in its formulation. The decrease in $\mathrm{pH}$ during the storage time can be explained by the increased concentration of $\mathrm{H}^{+}$ions due to increased free water and the additive calcium propionate presence (Borges et al., 2012).

The sweet biscuits hardness increased up to 108 days of storage, but then decreased, but the mean value higher than the initial one (Figure 1F). However, the biscuits maintained their hardness satisfactory for at least 6 months of storage, independent of temperature. The correlation between water activity and hardness (0.62) was significant at the 5\% level. The changes undergone by food hardness are directly linked to structural changes undergone during its storage. Water, due to its plasticizing effect, is one of the main elements responsible for these changes. This results in a high mobility for starch. In forming a gel, amylose molecules can approach, join to form crystalline zones, that is called retrogradation. Thus, it can be reduced in volume and syneresis (the expulsion of water molecules). This phenomenon is time dependent and influenced by moisture content and storage temperature. Katz \& Labuza (1981) studied the biscuits hardness depending on water activity and observed that crunchy foods showed changes in hardness when the water activity exceeded the range of $0.35-0.50$. This limit was not exceeded by the experimental biscuits in this work.

In this study, from 108 days of storage, while lifting moisture and water activity, there was a consequent reduction of the biscuits hardness. It has been reported that the mechanical action anti plasticizing of the water is a characteristic of products based on starch. Probably the biscuit by high compression forces in the presence of free water leads to filling the alveolar spaces, thereby reducing the free volume of the system and hardening biscuits (Chang et al., 2000).

\subsection{Kinetics of physico-chemical changes during storage}

The water activity, moisture and hardness were directly related to the sensory biscuits characteristics. Kinetic models of water activity $(y=0.2451+0.0012 x ; y=0.2682+0.001 x)$ were zero-order because they showed the determination coefficient highest for both temperatures. According to the zero order models, the increase rate of water activity during storage for 180 days was $20 \%$ higher at $25^{\circ} \mathrm{C}$ to $35{ }^{\circ} \mathrm{C}$, because the rate constants were 0.0012 and 0.001 , respectively. The kinetic models $(y=1.8567+0.0236 x ; y=2.367+0.0174 x)$ that best explained the change phenomenon of moisture during storage also was the zero-order, as its showed the correlation coefficient highest and the average relative error lowest for both temperatures. It was observed that the slope is positive, that is, the moisture increased over the 180 days of storage, independent of temperature. 
The same trend was observed water activity from the increase in moisture rate, which in sweet biscuits stored at $25^{\circ} \mathrm{C}$ was $69 \%$ higher than $35^{\circ} \mathrm{C}$.

For biscuits hardness stored at $25^{\circ} \mathrm{C}$, the kinetic model that has been adapted also the zero-order $(y=47.087+0.0611 x)$. For the hardness of the biscuits stored at $35^{\circ} \mathrm{C}$ the kinetic model adapted was that most of the first order $(y=3.7977+0.016 x)$. It was found that for models of zero and first order the slope of the line was growing, with positive slope. Therefore there was an increase in hardness with time of storage. The increase in hardness was approximately 37 times faster at $25^{\circ} \mathrm{C}$, as can be verified by the rate constants of 0.0611 and 0.0016 for models of zero-order $\left(25^{\circ} \mathrm{C}\right)$ and first order $\left(35^{\circ} \mathrm{C}\right)$, respectively. At $10^{\circ} \mathrm{C}$ increase in temperature sweet biscuit storage $\left(25^{\circ} \mathrm{C}\right.$ to $\left.35^{\circ} \mathrm{C}\right)$, the elevation of water activity was slowed by $83 \%(\mathrm{Q} 10=0.83$ ) and the hardness was slowed down at $3 \%(\mathrm{Q} 10=0.03)$, while the deceleration achieved moisture of $74 \%(\mathrm{Q} 10=0.74)$. When the temperature is lower $\mathrm{RH}$ also decreases, causing water to evaporate quicker from a surface.

Thus, there is a water vapor trend contained in a air mass to condense on the product, absorbing the condensed water, a phenomenon called the "dew point". This was observed in the biscuit stored at $25^{\circ} \mathrm{C}$, where part of this water vapor condensed on the biscuit, which did raise the moisture and water activity of the same. The lower temperature may reduce the atmospheric air capacity to retain water in vapor form. This fact was also observed in the $25^{\circ} \mathrm{C}$ air has less capacity to hold water vapor inside the packaging that the $35^{\circ} \mathrm{C}$, which caused moisture and water activity rise faster in sweet biscuits stored in lower temperature (Baptista et al., 2007).

\subsection{Microbiological and sensory acceptance risk}

Even with increased moisture and water activity of biscuits during storage, storage temperature regardless, it was observed that these were stable from a microbiological point of view. The results for the microorganisms examined throughout the storage period were within the standards required by Brazilian Law, once for Coagulase Positive Staphylococci maximum count accepted is $10^{3}$ colony forming units (CFU) g ${ }^{-1}$ at $10^{2} \mathrm{CFU} \mathrm{g}^{-1}$ for Coliform $45^{\circ} \mathrm{C}$, while Salmonella must be absent every $25 \mathrm{~g}$ sample.

The time effect was significant at the $1 \%$ level of probability for all the sensory attributes evaluated while the temperature was only significant at $1 \%$ for appearance (factorial Anova). All attributes derived significant models $(\mathrm{p} \leq 0.01)$ and it was observed that the coefficient of determination ranged between 0.56 and 0.78 (Figure 2), which may be justified due to the large human desire variation that was mirrored in the analysis of acceptance.

There was less fluctuation in mean scores for appearance (Figure 2A) between the sweet biscuit stored at $25^{\circ} \mathrm{C}$, having a tendency to stability throughout the storage period. Already
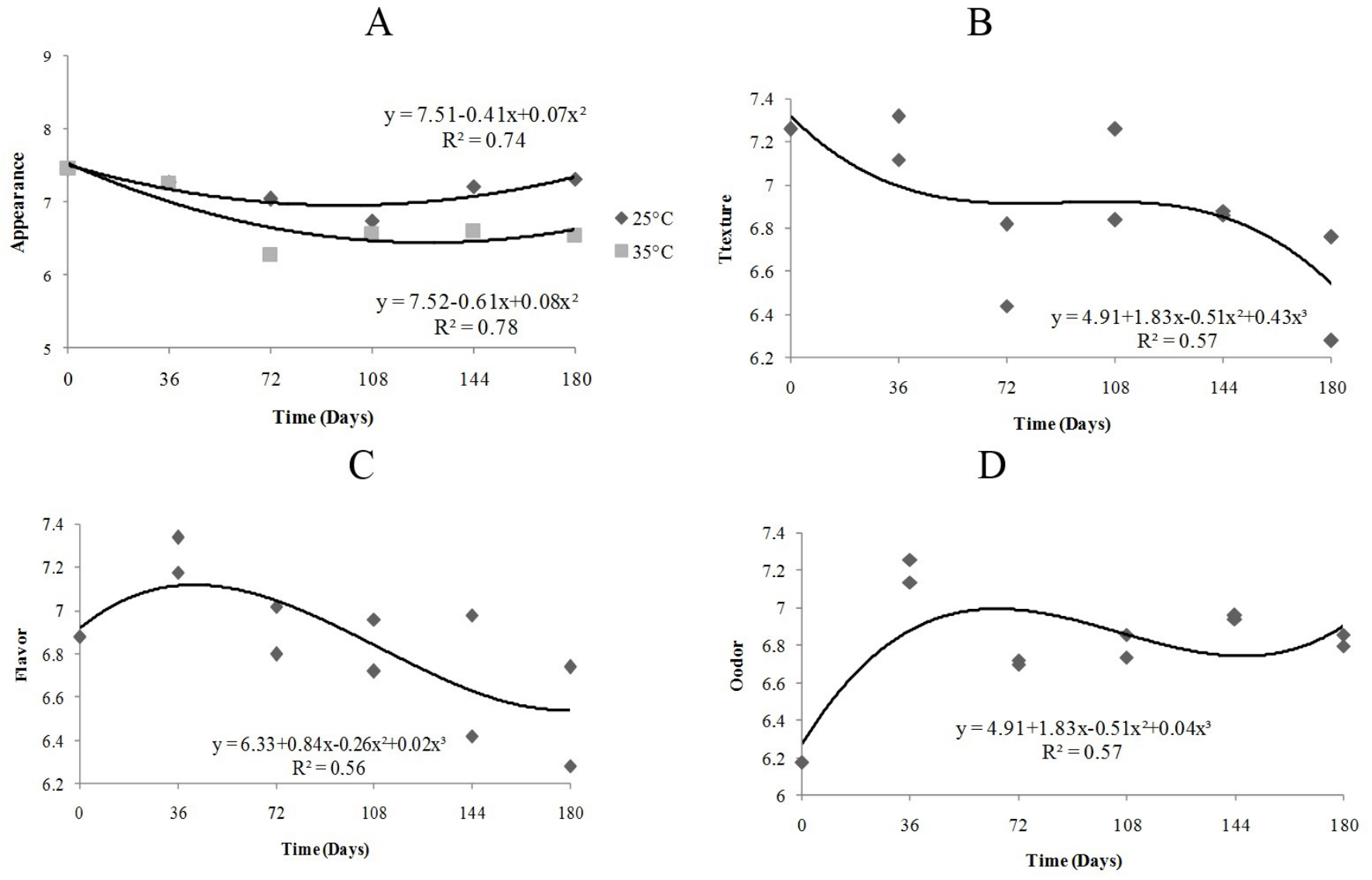

Figure 2. Score for A: appearance; B: texture; C flavor; and D odor of sweet biscuit type "rosquinhas", stored for 180 days. 
biscuits stored at $35{ }^{\circ} \mathrm{C}$ were reduced by $12.33 \%$ in the score for that attribute to the end of 180 days of storage. However, the minimum acceptance level, as established score six was not reached during storage.

The appearance was correlated inversely with the Chrome $b^{\star}(-0.76)$ at the level of $1 \%$ significance. This meant that the more yellowish the biscuit, the lower its acceptance by the tasters. Rodrigues et al. (2011) performed the characterization and sensory salt biscuit evaluation enriched flour with cassava meal, and observed the same trend. The biscuit with the highest Chrome $b^{*}$ had the lowest score for appearance.

The scores for sweet biscuit texture ranged from 7.32 to 6.28 over the limit of pre-established of acceptance (Figure 2B). Over time we found that the scores for the sweet biscuits were decreasing, reaching this reduction to $10.12 \%$ at 180 days compared to the average beginning score of the experiment. Unlike instrumental hardness, texture sensory score decreased over time, which shows that the tasters prefer less hard biscuits, since there was a increasing hardness with storage trend. The sensory texture correlated inversely with water activity $(-0.64)$ at the $1 \%$ level of significance, showing that the higher the water activity, the lower the score for sensory texture. Same correlation trend occurred between sensory texture and moisture $(-0.65)$, the $1 \%$ significance level.

Considering the sweet biscuits scores for flavor, there was a trend toward a reduction of the score from 36 days of storage, resulting in a reduction of $10.33 \%$ between 36 and 180 days of storage (Figure $2 \mathrm{C}$ ). It was observed that the score for flavor was inversely moisture biscuits trend, thus showing that the more increased the biscuits moisture, most reduced acceptance. It has been observed that by 72 days of storage gave an increase of $9.52 \%$ to score the sweet biscuits odor (Figure 2D). After this period there was a tendency to stability. The water activity showed a positive relationship with the odor at the $5 \%$ level of significance. Same effect when evaluating the relationship between odor and moisture and odor and hardness, both at the 5\% level of significance. According Faria \& Yotsuyanagi (2002), volatility may be affected by the product surface conditions, with more volatile escape from a soft, porous, moist than a smooth, dry surface. Thus, increased moisture, water activity and hardness assisted in the odor volatilization of sweet biscuits.

\section{Conclusion}

The sweet biscuits of wheat flour and potato starch acidified and dehydrated have good physical and microbiological conditions, being able to be consumed for a period of 180 days. The potato starch recovered after acidified and dehydrated can be used as an ingredient in the products development for human consumption, avoiding losses and environmental pollution, and to generate economic gains.

\section{Acknowledgements}

To CAPES for fellowship support.

\section{References}

Adebowale, A. A., Adegoke, M., Sanni, S. A., Adegunwa, M. O., \& Fetuga, F. O. (2012). Functional properties and biscuit making potentials of sorghum-wheat flour composite. American Journal of Food Technology, 7(6), 372-379. http://dx.doi.org/10.3923/ajft.2012.372.379.

Ascheri, D. P. R., Ribeiro, M. M., Ascheri, J. L. R., \& Carvalho, C. W. P. (2005). Isotermas de adsorción de agua y estabilidad de harinasextruídas de amaranto, arroz y maíz: estudio comparativo. Alimentaria, 363(5), 100-107.

Association of Official Analytical Chemists - AOAC. (2012). Official methods of analysis of AOAC international: food composition, additives, natural contaminants (19th ed., Vol. 2). Gaithersburg: AOAC International.

Baljeet, S. Y., Ritika, B. Y., \& Roshan, L. Y. (2010). Studies on functional properties and incorporation of buckwheat flour for biscuit making. International Food Research Journal, 17, 1067-1076.

Baptista, P., Gaspar, P. D., \& Oliveira, J. (2007). Higiene e segurança alimentar na distribuição de produtos alimentares (1 th ed.). Coimbra: Forvisão.

Batista, J. E. R., Morais, M. P., Caliari, M., \& Soares, M. S. Jr. (2016). Physical, microbiological and sensory quality of gluten-free biscuits prepared from rice flour and potato pulp. Journal of Food and Nutrition Research, 55(2), 101-107.

Bastos, G. M., Soares, M. S. Jr., Caliari, M., Pereira, A. L. A., Morais, C. C., \& Campos, M. R. H. (2016). Physical and sensory quality of gluten-free spaghetti processed from amaranth flour and potato pulp. Lebensmittel-Wissenschaft + Technologie, 65(1), 128-136. http:// dx.doi.org/10.1016/j.lwt.2015.07.067.

Borges, J. T. D. S., Paula, C. D., Pirozi, M. R., \& Oliveira, K. (2012). Qualidade nutricional de pão de forma enriquecido com farinha de quinoa. Alimentos Hoy, 21(27), 55-67.

Brasil, Agência Nacional de Vigilância Sanitária. (2005, September 22). Resolução RDC $n^{\circ} 263$, de 22 de setembro de 2005. Aprova o regulamento técnico para produtos de cereais, amidos, farinhas e farelos. Diário Oficial da República Federativa do Brasil.

Carvalho, W. T., Oliveira, T. F., Silva, F. A., Caliari, M., \& Soares, M. S. Jr. (2014). Drying kinetics of potato pulp waste. Food Science and Technology (Campinas), 34(1), 116-122. http://dx.doi.org/10.1590/ S0101-20612014000100017.

Chang, Y. P., Cheah, P. B., \& Seow, C. C. (2000). Plastizating-antiplasticizating effects of water on physical properties of tapioca starch films in the glassy state. Journal of Food Science, 65(3), 445-451. http://dx.doi. org/10.1111/j.1365-2621.2000.tb16025.x.

Clerici, M. T. P. S., Oliveira, M. E., \& Nabeshima, E. H. (2013). Physical, chemical and sensory quality of cookies elaborated with partial substitution of wheat flour by defatted sesame flour. Brazilian Journal of Food Technology, 16(2), 139-146. http://dx.doi.org/10.1590/ S1981-67232013005000017.

Dias, T. L., Oliveira, T. F., Campos, M. R. H., \& Soares, M. S. Jr. (2014). Utilização da polpa de batata residual em snacks como perspectiva de redução do impacto ambiental. Revista Brasileira de Engenharia Agrícola e Ambiental, 18(2), 225-230. http://dx.doi.org/10.1590/ S1415-43662014000200014.

Faria, E. V., \& Yotsuyanagi, K. (2002). Técnicas de análise sensorial (1th. ed.). Campinas: Ital/Lafise.

Food and Drug Administration - FDA. (2002). Bacteriologicalanalytical manual. Silver Spring: FDA. Retrieved from: http//:www.cfsan.fda. gov/ eban/ban-4html 
Katz, E. E., \& Labuza, T. P. (1981). Effect of water activity on the sensory crispness and mechanical deformation of snack food products. Journal of Food Science, 46(2), 403-409. http://dx.doi. org/10.1111/j.1365-2621.1981.tb04871.x.

Melo, M. P., Lima, D. P., \& Pinheiro, P. R. (2004). Modelos em programação matemática para o processamento do biscoito tipo cracker. Food Science and Technology (Campinas), 24(3), 363-368. http://dx.doi. org/10.1590/S0101-20612004000300010.

Rodrigues, J. P. M., Caliari, M., \& Asquieri, E. R. (2011). Caracterização e análise sensorial de biscoitos de polvilho elaborados com diferentes níveis de farelo de mandioca. Ciência Rural, 41(12), 2196-2202. http://dx.doi.org/10.1590/S0103-84782011001200025.

Santos, F. S. A., Figueirêdo, R. M. F., \& Queiroz, A. J. M. (2004). Isotermas de adsorção de umidade de farinhas de mandioca temperadas. Revista Brasileira de Produtos Agroindustriais, 6(2), 149-155. http://dx.doi. org/10.15871/1517-8595/rbpa.v6n2p149-155.

Sperber, W. H. (2009). Introduction to the microbiological spoilage of foods and beverages. In: W. Sperber \& M. Doyle (Eds.). Compendium of the microbiological spoilage of foods and beverages (pp. 1-40). Griffin: Springer. http://dx.doi.org/10.1007/978-1-4419-0826-1_1.

Stable Micro Systems (2013). User manual: Texture Analyser TA.HD. plus. Versions Expoent Lite Software 6.10.4.0. Godalming: Stable Micro Systems.

Syamaladevi, R. M., Tang, J., Villa-Rojas, R., Sablani, S., Carter, B., \& Campbell, G. (2016). Influence of water activity on thermal resistance of microorganisms in low-moisture foods: a review. Comprehensive Reviews in Food Science and Food Safety, 15(2), 353-370. http:// dx.doi.org/10.1111/1541-4337.12190.

Stone, H., Bleibaum, R., \& Thormas, H. (2012). Sensory evaluation practices (4th ed.). New York: Academic Press.

Vendramini, R. (2014, April 25). Acumulado de chuva está 152\% acima da média para abril em Goiânia. Tempo Agora. Retrieved from: http://www.tempoagora.com.br/noticias/59880/acumulado-dechuva-esta-152-acima-da-media-para-abril-em-goiania 